\title{
FREQUENCY AND RISK FACTORS FOR TOXOCARIASIS IN CHILDREN FROM A PEDIATRIC OUTPATIENT CENTER IN SOUTHEASTERN BRAZIL
}

\author{
Cristiane Rodrigues TEIXEIRA(1), Pedro Paulo CHIEFFI(2), Suzana A. Z. LESCANO(2), Elisabete Ourique de Melo SILVA(3), Blima FUX(4) \\ \& Márcia Cristina CURY(1)
}

\begin{abstract}
SUMMARY
To estimate the frequency of anti-Toxocara sp. antibodies, and evaluate factors associated with this infection, sera from 242 male and female children, aged from one to fifteen years old, attended at the Hospital of the Federal University of Uberlândia, Minas Gerais State, Brazil, were analyzed by ELISA. Information on the patients was collected and registered using an investigative questionnaire, and details on possible clinical alterations were obtained from the medical charts of 187 patients. Of a total of 242 samples, $21(8.7 \%)$ were positive for anti-Toxocara sp. antibodies. The presence of dogs and cats and the school variable (place of contact), appeared to be significantly associated $(\mathrm{p}<0.05)$ with a positive serology. Respiratory symptoms and eosinophil counts greater than $20 \%$ also showed a positive statistical correlation with a positive serology for Toxocara sp.. Factors such as sex and age, and symptoms like headache, stomach ache, convulsive crises and anemia were not associated with toxocariasis.
\end{abstract}

KEYWORDS: Toxocara canis; Toxocariasis; Risk factors.

\section{INTRODUCTION}

BEAVER et al. ${ }^{7}$ defined Visceral Larva Migrans syndrome (VLM) as a prolonged migration of helminth larvae within the organism of unusual hosts. Toxocara canis and T. cati are common ascarid parasites of dogs and cats, and are considered to be the principal etiological agents of the syndrome ${ }^{4}$. Humans become infected after the ingestion of either embrionated ascarid eggs or of tissues from infected paratenic hosts ${ }^{24}$.

Human infection by Toxocara sp. is distributed worldwide and appears in variable frequencies, depending on local factors such as close contact with soil contaminated by dog feces, and low income levels of the exposed community ${ }^{1,33}$. The rate of infection and occurrence of symptoms are more frequent in young children up to the age of 12 years old, mainly in rural areas; however, adults, are also infected ${ }^{4,17}$. The most common signs and symptoms of infection include fever, respiratory complaints and hepatomegaly. However, in most cases, there are no clinical manifestations, and the disease develops in an asymptomatic manner ${ }^{36}$. With regard to the clinical spectrum of toxocariasis, the principal finding from the last 25 years is that the disease can exhibit a distinct clinical picture ${ }^{25,39}$, known as covert toxocariasis. The current generally accepted classification of human toxocariasis includes covert toxocariasis, ocular toxocariasis and neurological toxocariasis.
Various studies have investigated human infection by Toxocara sp. in Brazil, usually reporting high frequencies ${ }^{1,4,11,12,33}$.

The laboratory diagnosis of human Toxocara infection relies mainly on a $T$. canis larval excretory-secretory (TcES) antigen based enzymelinked immunosorbent assay (ELISA), which is said to show $78 \%$ sensitivity and $92 \%$ specificity $^{23}$.

The present study aims to establish the frequency of anti-Toxocara antibodies in children attended at the pediatric center of the Hospital of the Universidade Federal de Uberlândia, Minas Gerais State, Brazil. In addition, we attempt to identify certain risk factors associated with the infection.

\section{MATERIAL AND METHODS}

The pediatric center of the Hospital of the Universidade Federal de Uberlândia (HC-UFU) is a children's reference center for the Uberlândia municipal district in Minas Gerais State, Brazil, and attends almost all pediatric cases related to public health.

Blood was collected from 242 children, male and female, aged between one and fifteen years old, randomly selected and attended at the pediatric center of HC-UFU, during the period between February and September, 2004. Children infected with different diseases, without 


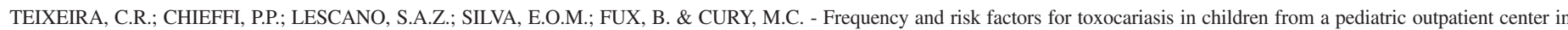
southeastern Brazil. Rev. Inst. Med. trop. S. Paulo, 48(5): 251-255, 2006.

specific toxocariasis manifestations, were included in the study. A semistructured questionnaire was given to the study participants to register patient history (sex, age, and origin) environmental and behavioral data (geophagy, contact with sand, contact site and presence of dogs and cats). Information on possible specific clinical signs (respiratory complications, headache, stomach ache, convulsive crises, anemia, eosinophilia) was obtained from the patients' medical charts. Only 187 of the 242 patients completed the questionnaire.

A total IgG anti-Toxocara sp. antibody test was performed using the ELISA immuno-enzymatic method, employing secretory-excretory antigens from second stage larvae $\left(\mathrm{L}_{2}\right)$ cultivated in vitro in accordance with the technique of de SAVIGNY ${ }^{14}$. All sera were absorbed with total Ascaris suum antigenic extract to avoid cross-reaction between the Toxocara sp. antigens and Ascaris sp. antibodies ${ }^{6,14,15}$. A goat antihuman IgG (Gamma-Chain) specific peroxidase conjugate was used. Absorbance was read at $492 \mathrm{~nm}$ to establish optical density; sera with titers higher than or approximating 1:160 were considered positive ${ }^{11}$.

Epi Info 6.04 software was used for statistical analysis. A descriptive unvariate analysis was performed to evaluate the frequency of the variables (risk factors) and anti-Toxocara sp. antibodies, estimated using an Odds ratio. The relative proportions were calculated with a confidence interval of $95 \%$. Possible associations were identified using the Chi-squared and Fisher's exact statistical tests at a significance level of $5 \%$.

The present protocol was evaluated and approved with no ethical restrictions by the Ethics Committee of the Universidade Federal de Uberlândia ( $n^{\circ} 107 / 2002$ - CEP/UFU-07/02/2003).

\section{RESULTS}

Of the 242 children's serum samples, 21 (8.7\%) were positive for anti-Toxocara antibodies. Of these, 14 were from males $(66.7 \%)$ and 7 from $(33.3 \%)$ females, whose average age was 5.8 years, with a standard deviation of 3.04 years. Of the positive patients investigated, $19(90.5 \%)$ lived in urban areas of Uberlândia, and $2(9.8 \%)$ were from nearby towns. Sex, age, origin and origin site variables showed no significant relationship ( $\mathrm{p} \geq 0.05$ ) with positive serology for anti-Toxocara $\mathrm{sp}$. antibodies.

The presence of animals and the place of contact with sand showed a significant association ( $\mathrm{p} \leq 0.05$ ) with positive anti-Toxocara $\mathrm{sp}$. antibodies in the sera analyzed. The presence of dogs or cats was not significantly associated with seropositivity. However when both dogs and cats were present at the residence there was a 3.57-fold greater risk of a positive serology for toxocariasis compared to residents without these animals. This association was statistically significant $(\mathrm{p} \leq 0.05)$. The school variable (place of contact) was significantly associated with $(\mathrm{p} \leq 0.05)$ the presence of anti-Toxocara sp. antibodies. There was no statistical association among seropositivity, sand contact and geophagy $(\mathrm{p} \geq 0.05)$ (Table 1).

Analysis of the clinical variables showed that breathing alterations correlated significantly ( $\mathrm{p} \leq 0.05$ ) with a positive serology for toxocariasis. Stomach ache, headache, convulsive crises, anemia and eosinophilia were not statistically associated ( $\mathrm{p} \geq 0.05)$ with the presence of anti-Toxocara sp. antibodies in the sera investigated.

The number of eosinophils was counted in 144 of 187 patients (77\%), and showed a statistically significant association with seropositivity to Toxocara $\mathrm{sp}$. antibodies ( $\mathrm{p} \geq 0.05$ ) (Table 2 ).

\section{DISCUSSION}

A frequency of $8.7 \%$ for anti-Toxocara sp. antibodies suggests that the children in the study population were in contact with the parasite, and developed an immune response with the production of specific antibodies. There are no reports on serological surveys for anti-Toxocara

Table 1

Distribution of anti-Toxocara sp. antibody frequencies (\%) and Odds Ratios according to environmental and behavioral variables in children attended at a pediatric center of the Hospital of the Federal University of Uberlândia, Brazil

\begin{tabular}{|c|c|c|c|c|c|c|c|}
\hline \multirow{2}{*}{ Variable } & & \multicolumn{2}{|c|}{ Sample (n) } & \multirow{2}{*}{$\begin{array}{l}\text { Anti-Toxocara sp. } \\
\text { antibodies }(\%)\end{array}$} & \multirow[t]{2}{*}{ OR } & \multirow[t]{2}{*}{$\mathrm{CI}$} & \multirow[t]{2}{*}{$p$} \\
\hline & & $\begin{array}{l}\text { Absolute } \\
\text { frequency }\end{array}$ & $\begin{array}{c}\text { Relative } \\
\text { frequency }(\%)\end{array}$ & & & & \\
\hline \multirow[t]{4}{*}{ Presence of animal } & Dog & 128.0 & 52.9 & 7.0 & 1.07 & $(0.33-3.8)$ & 0.89 \\
\hline & Cat & 6.0 & 2.5 & 33.3 & 7.08 & $(0.52-60.6)$ & 0.07 \\
\hline & Dog/Cat & 17.0 & 7.0 & 23.5 & 3.57 & $(1.13-11.32)$ & $0.04 *$ \\
\hline & None & 91.0 & 37.6 & 6.6 & 1.0 & & \\
\hline \multirow[t]{2}{*}{ Contact with sand } & No & 136.0 & 56.2 & 5.9 & 1.0 & & \\
\hline & Yes & 106.0 & 43.8 & 12.3 & 2.23 & $(0.89-5.61)$ & 0.08 \\
\hline \multirow[t]{4}{*}{ Sand contact site } & House & 85.0 & 35.1 & 9.4 & 1.65 & $(0.54-5.08)$ & 0.33 \\
\hline & School & 12.0 & 5.0 & 33.3 & 7.94 & $(1.40-37.7)$ & $0.009 *$ \\
\hline & House/School & 10.0 & 4.1 & 10.0 & 1.76 & $(0.04-15.92)$ & 0.48 \\
\hline & None & 135.0 & 55.8 & 5.9 & 1.0 & & \\
\hline \multirow[t]{2}{*}{ Geophagy } & No & 213 & 88 & 7.5 & 1.0 & & \\
\hline & Yes & 29 & 12 & 17.2 & 2.56 & $(0.67-8.1)$ & 0.08 \\
\hline
\end{tabular}

OD - Odds Ratio; CI - Confidence Interval; * - Significant values $\mathrm{p} \leq 0.05$ 


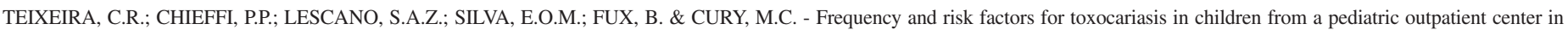
southeastern Brazil. Rev. Inst. Med. trop. S. Paulo, 48(5): 251-255, 2006.

Table 2

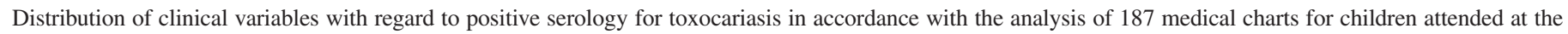
Hospital of the Federal University of Uberlândia, Brazil

\begin{tabular}{|c|c|c|c|c|c|c|c|c|}
\hline \multirow{3}{*}{ Variables } & & \multicolumn{6}{|c|}{ Anti-Toxocara sp. antibodies } & \multirow{3}{*}{$p$} \\
\hline & & \multicolumn{2}{|c|}{ Positive } & \multicolumn{2}{|c|}{ Negative } & \multicolumn{2}{|c|}{ Total } & \\
\hline & & No. & $\%$ & No. & $\%$ & No. & $\%$ & \\
\hline \multirow[t]{2}{*}{ Breathing problems } & Yes & 6.0 & 15.8 & 32.0 & 84.2 & 38.0 & 100 & $0.01 *$ \\
\hline & No & 7.0 & 4.7 & 142.0 & 95.3 & 149.0 & 100 & \\
\hline \multirow{2}{*}{ Stomach ache } & Yes & 2.0 & 10.5 & 17.0 & 89.5 & 19.0 & 100 & 0.62 \\
\hline & No & 11.0 & 6.5 & 157.0 & 93.5 & 168.0 & 100 & \\
\hline \multirow[t]{2}{*}{ Headache } & Yes & 1.0 & 10.0 & 9.0 & 90.0 & 10.0 & 100 & 0.9 \\
\hline & No & 12.0 & 6.9 & 161.0 & 93.1 & 173.0 & 100 & \\
\hline \multirow[t]{2}{*}{ Anemia } & Yes & 1.0 & 10.0 & 9.0 & 90.0 & 10.0 & 100 & 0.52 \\
\hline & No & 12.0 & 6.7 & 165.0 & 93.3 & 177.0 & 100 & \\
\hline \multirow[t]{2}{*}{ Epilepsy } & Yes & 2.0 & 16.6 & 10.0 & 83.4 & 12.0 & 100 & 0.19 \\
\hline & No & 11.0 & 6.3 & 164.0 & 93.7 & 175.0 & 100 & \\
\hline \multirow{2}{*}{ Eosinophilia } & Yes & 11.0 & 7.6 & 133.0 & 92.4 & 144.0 & 100 & 0.73 \\
\hline & No & 2.0 & 4.6 & 41.0 & 95.4 & 43.0 & 100 & \\
\hline \multirow[t]{2}{*}{ Eosinophilia } & $>20 \%$ & 5.0 & 55.5 & 4.0 & 44.4 & 9.0 & 100 & $0.0001 *$ \\
\hline & $\leq 20 \%$ & 6.0 & 4.4 & 129.0 & 95.6 & 135.0 & 100 & \\
\hline
\end{tabular}

* - Significant values; $\mathrm{p} \leq 0.05$

sp. antibodies in Uberlândia, Minas Gerais, and the known studies concern the prevalence of eggs and larvae in public parks ${ }^{13}$.

The lower seropositivity for anti-Toxocara sp. antibodies found in this study differs from other reports in Brazil ${ }^{2,4,31,33}$ and in other countries $^{21,32}$. Interpretation of seroprevalence data is still problematic owing to different cut-off titers used by the various investigators and difficulty in evaluating the relationship between antibody titers, infection and clinical findings for the disease. Prevalence data based on hospitalized patients' serum, blood donors and high risk subgroups tend to introduce bias and do not provide accurate population data ${ }^{1}$.

Observations from this study suggest the lack of a significant statistical association between sex, age or origin of the child and antiToxocara antibodies. Some areas with a high prevalence of human Toxocara infection do not show significant differences according to age $^{2}$. In the present study, the mean age of the seropositive children was 5.8 years old (standard deviation of 3.8 years). Most serological surveys have shown a predominance of seropositivity in children aged between two and 15 years old, considered to be the classic age group for susceptibility to toxocariasis ${ }^{1,3}$. BUNDY et al. ${ }^{9}$ suggested that the prevalence rates of infection may provide some indication of an ageinfection relationship, and that the rates found for the under five years old age group probably constitute a true reflection of infection acquisition rate, since this population is not infected at birth. MAGNAVAL et al. ${ }^{29}$ and THOMPSON et al..$^{40}$, studying two tropical areas of intense transmission, demonstrated a progressive increase in seroprevalence up to 25-30 years of age, and occasionally over this limit, suggesting that toxocariasis may no longer be considered an exclusively pediatric zoonosis. Gender does not seem to be an important factor regarding $T$. canis infection among healthy children in this study, although a higher frequency was observed in males. Several studies have shown a higher frequency of Toxocara infection in male individuals, which may derive from differences in the play and social behaviors of boys, resulting in increased exposure to the eggs of Toxocara $\mathrm{sp}^{24,35}$. However, EHRHARD \& KERNHAUM ${ }^{16}$ noted a predominance of women among adult patients, and FENOY et al. ${ }^{19}$ and LJUNGSTROME \& KNAPEN ${ }^{27}$ observed a greater frequency in rural communities. The high prevalence for Toxocara serology may result from various factors, the most important of which concerns living conditions associated with urban infrastructure. Individuals residing in houses whose walls directly delimit the garden, in addition to those who filter their drinking water, had significantly lower frequencies of Toxocara infection ${ }^{5}$.

Some environmental and behavioral variables were significantly associated with the positive anti-Toxocara antibody responses. Regarding the presence of animals, there is controversy as to the importance of contact with dogs as a risk factor for human toxocariasis. CHIEFFI et al..$^{10}$ and SCHANTZ et al. ${ }^{37}$, reported a higher frequency of infection in individuals who were in contact with dogs, however, other studies found no association between ownership or professional contact with dogs and Toxocara infection ${ }^{22,26}$. FAN et al. ${ }^{18}$ observed high seropositive rates in $79.4 \%$ of dog owners, and $67.9 \%$ in nonowners, suggesting that these two groups are equally at risk of infection. These results are in line with those of WOODRUFF et al. ${ }^{42}$ who observed that $50 \%$ of patients with clinical toxocariasis owned dogs. In the current study, the presence of cats tended to increase the risk of infection, although not statistically significant, probably owing to the small sample size. However, the presence of both cats and dogs together significantly increased risk; since the data do not show an increased risk among those who own dogs alone, presumably the contact with cats influenced the results. MUNDIM et al. ${ }^{34}$ report that in addition to $T$. cati, cats may also be infected with $T$. canis, and although $T$. canis accounts for the greater part of larva migrans in human beings, T. cati is apparently responsible for ocular and visceral changes ${ }^{20}$. 


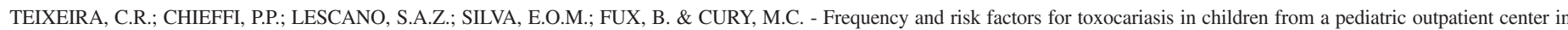
southeastern Brazil. Rev. Inst. Med. trop. S. Paulo, 48(5): 251-255, 2006.

In this study, geophagy and contact with soil did not to contribute to the risk of infection by toxocariasis, contradicting findings by AJAYI et al. $^{2}$ showing highly significant association between seropositivity and geophagy. Contact with soil tended to be associated with risk of infection by the parasite; however, the association was not statistically significant $($ Odds ratio $=2.23 / \mathrm{CI}=0.89-5.61)$.

The school variable is a risk factor for children playing in such areas. WORLEY et $a l .{ }^{43}$ showed that positive titers for anti-Toxocara sp. antibodies are not related to the fact that children attend school, but rather to a group of factors linked to the hygienic and behavioral habits of the children. The school may offer a greater risk of infection owing to the presence of small areas covered with sand where the children play, which may be contaminated.

We found a statistical correlation between the presence of antiToxocara sp. antibodies and breathing difficulties. This positive correlation also has been mentioned by SNYDER $^{38}$ who considered it to be a toxocariasis specific disorder. MACHADO \& $\mathrm{ACHKAR}^{28}$, emphasized that toxocariasis is associated with multiple clinical characteristics and may be confused with other diseases.

Hematological alterations have been described in clinical cases of toxocariasis ${ }^{30,41}$ and BEAVER et al. ${ }^{7}$ reported a close relationship between eosinophilia and visceral larva migrans. In the present study, anemia or eosinophilia were not statistically correlated with the presence of antiToxocara sp. antibodies, which agrees with findings by ANARUMAFILHO et al. ${ }^{5}$. However, considering those children with high eosinophil counts, eosinophilia $20 \%$ higher than the statistically significant limit may be associated with Toxocara sp. infection (Table 2).

The current study confirms the presence of anti-Toxocara sp. antibodies in children from the municipality of Uberlândia, Minas Gerais, a situation that represents a considerable health problem for this population, particularly children. Studies employing a large sample size are necessary to evaluate the real situation, and thus to implement measures aiming to reduce infection risk factors.

\section{RESUMO}

\section{Freqüência e fatores de risco associados à toxocaríase em crianças de ambulatório pediátrico na região sudeste do Brasil}

Para determinar a frequência de anticorpos anti-Toxocara sp. e os fatores de risco associados à infecção, soros de 242 crianças de ambos os sexos, com idade entre um a 15 anos, atendidas no ambulatório do Hospital da Universidade Federal de Uberlândia, Minas Gerais, Brasil, foram analisados pelo ELISA. Questionários foram aplicados, para obter informações sobre os pacientes. As informações sobre as alterações clínicas, de 187 pacientes, foram obtidas no prontuário médico. Do total das 242 amostras, 21 (8,7\%) foram positivas para anticorpos anti-Toxocara sp.. A presença de cães e gatos e a variável escola (local de contato) sugerem associação significativa $(\mathrm{p}<0.05)$ com a sorologia positiva. Sintomas respiratórios e elevada contagem de eosinófilos (> 20\%) mostram correlação positiva com a soropositividade para Toxocara sp.. A idade, sexo, sintomas como dor de cabeça, dor estomacal, crises convulsivas e anemia não apresentaram associação com toxocaríase.

\section{REFERENCES}

1. AgUiAR-SANTOS, A.M.; ANDRADE, L.D.; MEDEIROS, Z. et al. - Human toxocariasis: frequency of anti-Toxocara antibodies in children and adolescents from an outpatient clinic for lymphatic filariasis in Recife northeast Brazil. Rev. Inst. Med. trop. S. Paulo, 40: 81-85, 2004.

2. AJAYI, O.O.; DUHLINSKA, D.D.; AGWALE, S.M. \& NJOKU, M. - Frequency of human toxocariasis in Jos, Plateau State, Nigeria. Mem. Inst. Oswaldo Cruz, 95: 147-149, 2000

3. ALDERETE, J.M.S.; JACOB, C.M.A; PASTORINO, A.C. et al. - Prevalence of Toxocara infection in school children from the Butantã region, São Paulo, Brazil. Mem. Inst. Oswaldo Cruz, 98: 593-597, 2003.

4. ANARUMA-FILHO, F.; CHIEFFI, P.P.; CORREA, C.R.S. et al. - Human toxocariasis: incidence among residents in the outskirts of Campinas, State of São Paulo, Brazil. Rev. Inst. Med. trop. S. Paulo, 45: 293-294, 2003.

5. ANARUMA-FILHO, F.; CHIEFFI, P.P.; CORREA, C.R.S. et al. - Human toxocariasis: a seroepidemiological survey in the municipality of Campinas (SP), Brazil. Rev. Inst. Med. trop. S. Paulo, 44: 303-307, 2002.

6. BACH-RIZZATI, B.C. - Desenvolvimento de teste imunoenzimático, ELISA, para o diagnóstico da toxocaríase humana. São Paulo, 1984. (Dissertação de Mestrado Faculdade de Ciências Farmacêuticas da Universidade de São Paulo).

7. BEAVER, P.C.; SNYDER, C.H.; CARRERA, G.M.; DENT, J.H. \& LAFFERTY, J.W. Chronic eosinophilia due to visceral larva migrans. Report of three cases. Pediatrics, 9: 7-19, 1952.

8. BEAVER, P.C. - Toxocarosis (Visceral larva migrans) in relation to tropical eosinophilia. Bull. Soc. Path. éxot., 55: 555-576, 1962.

9. BUNDY, D.A.P.; THOMPSON, D.E.; ROBERTSON, B.D. \& COOPER, E.S. - Agerelationships of Toxocara canis seropositivity and geohelminth infection prevalence in two communities in St. Lucia, West Indies. Trop. Med. Parasit., 38: 309-312, 1987.

10. CHIEFFI, P.P.; UEDA, M.; CAMARGO, E.D. et al. - Contato domiciliar e profissional com cães como fatores de risco para infecção humana por larvas de Toxocara. Rev. Inst. Med. trop. S. Paulo, 30: 379-382, 1988.

11. CHIEFFI, P.P.; UEDA, M.; CAMARGO, E.D. et al. - Visceral larva migrans: a seroepidemiological survey in five municipalities of São Paulo State, Brazil. Rev. Inst. Med. trop. S. Paulo, 32: 204-210, 1990.

12. COELHO, L.M.P.S.; SILVA, M.V.; DINI, C.Y. et al. - Human toxocariasis: a seroepidemiological survey in schoolchildren of Sorocaba, Brazil. Mem. Inst. Oswaldo Cruz, 99: 553-557, 2004.

13. COSTA-CRUZ, J.M.; NUNES, R.S. \& BUSO, A.G. - Presença de ovos de Toxocara spp. em praças públicas da cidade de Uberlândia, Minas Gerais, Brasil. Rev. Inst. Med. trop. S. Paulo, 36: 39-42, 1994.

14. DE SAVIGNY, D.H. - "In vitro" maintenance of Toxocara canis larvae and a simple method for the production of Toxocara ES antigen for use in serodiagnostic tests for visceral larva migrans. J. Parasit., 61: 781-782, 1975.

15. DE SAVIGNY, D.H.; VOLLER, A. \& WOODRUFF, A.W. - Toxocariasis: serological diagnosis by enzyme immunoassay. J. clin. Path., 32: 284-288, 1979.

16. EHRHARD, T. \& KERNBAUM, S. - Toxocara canis et toxocarose humaine. Bull. Inst. Pasteur, 77: 225-287, 1979.

17. EMBIL, J.A.; TANNER, C.E.; PEREIRA, L.H. et al. - Seroepidemiologic survey of Toxocara canis infection in urban and rural children. Publ. HIth (Lond.), 102: 129133, 1988. 
18. FAN, C.K.; HUNG, C.C.; DU, W.Y.; LIAO, C.W. \& SU, K.E. - Seroepidemiology of Toxocara canis infection among mountain aboriginal schoolchildren living in contaminated districts in eastern Taiwan. Trop. Med. int. Hlth, 9: 1312-1318, 2004.

19. FENOY, S.; CUÉLLAR, C. \& GUILLÉN, J.L. - Serological evidence of toxocariasis in patients from Spain with a clinical suspicion of visceral larva migrans. J. Helminth. 71: 9-12, 1997.

20. FISHER, M. - Toxocara cati: an underestimated zoonotic agent. Trends Parasit., 19: 167-170, 2003.

21. GENCHI, C.; DI SACCO, B.; GATTI, S.; SANGALLI, G. \& SCAGLIA, M. Epidemiology of human toxocariasis in northern Italy. Parassitologia, 32: $313-$ $319,1990$.

22. GLICKMAN, L.T. \& CYPESS, R.H. - Toxocara infection in animal hospital employees. Amer. J. publ. Hlth, 67: 1193-1195, 1977.

23. GLICKMAN, L.T.; SCHANTZ, P.M.; DOMBROSKE, R. \& CYPESS, R. - Evaluation of serodiagnostic tests for visceral larva migrans. Amer. J. trop. Med. Hyg., 27: 492-498, 1978.

24. GLICKMAN, L.T. \& SCHANTZ, P.M. - Epidemiology and pathogenesis of zoonotic toxocariasis. Epidemiol. Rev., 3: 230-250, 1981.

25. GLICKMAN, L.T.; MAGNAVAL, J.F.; DOMANSKI, L.M. et al. - Visceral larva migrans in French adults: a new disease syndrome? Amer. J. Epidem., 125: 1019-1034, 1987.

26. JACOBS, D.E.; WOODRUFF, A.W.; SHAH, A.I. \& PROLE, J.H. - Toxocara infections and Kennel workers. Brit. med. J., 1: 51, 1977.

27. LJUNGSTROM, I. \& van KNAPEN, F. - An epidemiological and serological study of Toxocara infection in Sweden. Scand. J. infect. Dis,. 21: 87-93, 1989.

28. MACHADO, A.B. \& ACHKAR, M.E. - Larva migrans visceral: relato de caso. An. bras. Derm. (Rio de J.), 78: 215-219, 2003.

29. MAGNAVAL, J.F.; GLICKMAN, L.T. \& DORCHIES, P. - La toxocarose une zoonose helminthique majeure. Rev. Med. vet., 145: 611-627, 1994.

30. MAGNAVAL, J.F.; GLICKMAN, L.T.; DORCHIES, P. \& MORASSIN, B. - Highlights of human toxocariasis. Korean J. Parasit., 39: 1-11, 2001.

31. MATOS, M.F.; MILITÃO, D.N.A.; BRUM, M.A.R. et al. - Presence of anti-Toxocara antibodies in children selected at Hospital Universitário, Campo Grande, MS, Brazil. Rev. Inst. Med. trop. S. Paulo, 39: 49-50, 1997.
32. MINVIELLE, M.C.; TAUS, M.R.; RAFFO, A.; CIARMELA, M.L. \& BASUALDO, J.A. - Seroprevalence of toxocariasis in blood donors of Gualeguaychú, Argentina. Trans. roy. Soc. trop. Med. Hyg., 94: 373-375, 2000.

33. MOREIRA-SILVA, S.F.; LEÃO, M.E.; MENDONÇA, H.F.S. \& PEREIRA, F.E.I. Prevalence of anti-Toxocara antibodies in a random sample of inpatients at a children's hospital in Vitória, Espírito Santo, Brazil. Rev. Inst. Med. trop. S. Paulo, 40: 259$261,1998$.

34. MUNDIM, T.C.D.; OLIVEIRA JÚNIOR, S.D.; RODRIGUES, D.C. \& CURY, M.C. Frequência de helmintos em gatos de Uberlândia, Minas Gerais. Arq. bras. Med. vet. Zootec., 56: 562-563, 2004.

35. OVERGAAUW, P.A.M - Aspects of Toxocara epidemiology: toxocariosis in dogs and cats. Crit. Rev. Microbiol., 23: 233-251, 1997.

36. SCHANTZ, P.M. - Toxocara larva migrans now. Amer. J. trop. Med. Hyg., 41: 21-34, 1989.

37. SCHANTZ, P.M.; WEIS, P.E.; POLLARD, Z.F. \& WHITE, M.C. - Risk factors of toxocaral ocular larva migrans: a case- control study. Amer. J. publ. Hlth, 70: 12691272,1980

38. SNYDER, C.H. - Visceral larva migrans. Ten years' experience. Pediatrics, 28: 85-91, 1961.

39. TAYLOR, M.R.; KEANE, C.T.; O' CONNOR, P.; MULVIHILL, E. \& HOLLAND, C. The expanded spectrum of toxocaral disease. Lancet, 1(8587): 692-695, 1988.

40. THOMPSON, D.E.; BUNDY, D.A.; COOPER, E.S. \& SCHANTZ, P.M. - Epidemiological characteristics of Toxocara canis zoonotic infection of children in Caribbean community. Bull. Wld Hlth Org., 64: 283-290, 1986.

41. van KNAPEN, F. \& BUIJS, J. - Diagnosis of Toxocara infection. In: LEWIS, J.W. \& MAIZEL, R.M. Toxocara and toxocariasis. Clinical, epidemiological and molecular perspectives. London, British Society for Parasitology, 1993. p. 49-53.

42. WOODRUFF, A.W.; DE SAVIGNY, D.H. \& JACOBS, D.E. - Study of toxocaral infection in dogs breeders. Brit. med. J., 2: 1747-1748, 1978.

43. WORLEY, G.; GREEN, J.A.; FROTHIGHAM, T.E. et al. - Toxocara canis infection: clinical and epidemiological associations with seropositivity in kindergarten children. J. infect. Dis, 149: 591-597, 1984.

Received: 12 April 2006

Accepted: 17 May 2006 